\title{
A new species of Symbra (Hymenoptera, Eurytomidae, Heimbrinae) from dry forest in Brazil and new occurrence records for other Heimbrinae
}

\author{
Daniell Rodrigo Rodrigues Fernandes ${ }^{1}$, Rogéria Inês Rosa Lara ${ }^{2} \&$ Nelson Wanderley Perioto ${ }^{1,2}$
}

${ }^{1}$ Universidade Estadual Paulista "Júlio de Mesquita Filho", Faculdade de Ciências Agrárias e Veterinárias, Programa de Pós-graduação em Agronomia (Entomologia Agrícola), Via de Acesso Prof. Paulo Donato Castellane, s/n, 14888-900, Jaboticabal, SP, Brazil. daniellrodrigo@hotmail.com

${ }^{2}$ Agência Paulista de Tecnologia dos Agronegócios, Av. Bandeirantes 2419, 14030-670, Ribeirão Preto, SP, Brazil.

rirlara@yahoo.com.br; nperioto2@gmail.com

\begin{abstract}
A new species of Symbra (Hymenoptera, Eurytomidae, Heimbrinae) from dry forest in Brazil and new occurrence records for other Heimbrinae. The geographic ranges of Heimbra opaca (Ashmead, 1894), H. bicolor Subba Rao, 1978 and H. parallela Stage \& Snelling, 1986 are extended based on study of material deposited in the entomological collections of the Laboratório de Sistemática e Bioecologia de Parasitoides e Predadores da APTA (Ribeirão Preto, SP, Brazil) of the Instituto Brasileiro de Geografia e Estatística (Brasília, DF, Brazil). Symbra potiguara Perioto \& Fernandes sp. nov. (Hymenoptera, Eurytomidae) is described, illustrated and compared with S. cordobensis Stage \& Snelling, 1986, the single species previously known for this genus. A key to the genera of Heimbrinae and to the species of Symbra is provided.
\end{abstract}

KEYWORDS. Brazil; Chalcidoidea; Heimbra; parasitoid.

RESUMO. Uma nova espécie de Symbra (Hymenoptera, Eurytomidae, Heimbrinae) de uma área de Caatinga e novos registros de ocorrência de outros Heimbrinae. Os limites geográficos de Heimbra opaca (Ashmead, 1894), H. bicolor Subba Rao, 1978 e H. parallela Stage \& Snelling, 1986 são estendidos com base no material examinado das coleções entomológicas do Laboratório de Sistemática e Bioecologia de Parasitoides e Predadores da APTA (Ribeirão Preto, SP, Brasil) e do Instituto Brasileiro de Geografia e Estatística (Brasília, DF, Brasil). Symbra potiguara Perioto \& Fernandes sp. nov. (Hymenoptera, Eurytomidae) é descrita, ilustrada e comparada com a única espécie conhecida desse gênero, S. cordobensis Stage \& Snelling, 1986. Uma chave para os gêneros de Heimbrinae e para as espécies de Symbra é fornecida.

PALAVRAS-CHAVE. Brasil; Chalcidoidea; Heimbra; parasitoide.

Heimbrinae is a small and rare subfamily of Eurytomidae with two genera: Heimbra Cameron, 1909, with six described species (H. acuticollis Cameron, 1909, H. bicolor Subba Rao, 1978, H. nigra Subba Rao, 1978, H. opaca (Ashmead, 1894), H. pallida Stage \& Snelling, 1986, H. parallela Stage \& Snelling, 1986) and Symbra Stage \& Snelling, 1986, comprising only S. cordobensis Stage \& Snelling, 1986 (Noyes 2007). Heimbrinae is restricted to the New World (Gates \& Hanson 2006) and may be easily distinguished from all others eurytomids by the scutellum peculiarly produced and dorsally flattened and the gaster heavily sclerotized and partially fused. While the hosts of Heimbra are, probably, stemboring Buprestidae and Curculionidae (Coleoptera), nothing is known about the hosts of Symbra (Stage \& Snelling 1986). Both genera are very poorly represented in entomological collections.

Except for H. opaca, which is the species most frequently collected and of which 53 specimens are known (42 from USA and 11 from Mexico) and for H. nigra, of which 12 specimens are known (11 from Argentina and one from Uruguay), the other species seem to be very rare: H. bicolor, of which four specimens are known from Brazil, three from Mexico and one from Paraguay; H. parallela, three from
Argentina and two from Brazil; H. acuticollis, three from Argentina; H. pallida, one from Argentina; and S. cordobensis, two from Argentina.

The geographic distribution of Heimbra ranges from northern USA (Montana State, latitude about $47^{\circ} \mathrm{N}$, the northernmost locality record for H. opaca) to Argentina (Buenos Aires Province, latitude about $35^{\circ} \mathrm{S}$, location where $H$. nigra was collected further south), while Symbra was previously known only from Argentina (Cordoba Province, approximate latitude: $30^{\circ} \mathrm{S}$ ).

Here, a new species of Symbra from Brazil is described and the geographic ranges of $H$. opaca, $H$. bicolor and $H$. parallela are expanded based on study of specimens deposited in the entomological collections at the Laboratório de Sistemática e Bioecologia de Parasitoides e Predadores da APTA (LRRP) (Ribeirão Preto, SP, Brazil) and at the Instituto Brasileiro de Geografia e Estatística (IBGE) (Brasília, DF, Brazil).

\section{MATERIAL AND METHODS}

Specimens of three species of Heimbrinae representing new occurrence records were found at LRRP and IBGE 
collections. The depository institutions where voucher specimens analyzed for the description of new records were deposited are listed under each species. This study on the geographic range of the species was based mainly on Stage \& Snelling (1986).

The female specimen of a new species of Symbra was obtained using a Malaise trap in a site within the Caatinga domain, in Mossoró $\left(05^{\circ} 01^{\prime} 10^{\prime \prime} \mathrm{S} / 37^{\circ} 22^{\prime} 56^{\prime \prime} \mathrm{W}\right)$, State of Rio Grande do Norte, Brazil.

Observations were carried out using a Leica MZ 9.5 stereomicroscope under fluorescent light source. Color images were obtained using a Leica DFC295 digital camera attached to a Leica M205C APO stereomicroscope, illuminated by a high diffuse dome illumination Leica LED5000 HDI. The serial images from different layers were combined using Helicon Focus software (version 5.2). The figures were prepared using Adobe Photoshop v.11.

The description format follows Stage \& Snelling (1986) in order to allow a comparison with the description of $S$. cordobensis. The terminology follows Gibson (1997) for general morphology and Harris (1979) for integument sculpturing.

Abbreviations are as follows: F $n$, flagellomeres ( $n=$ number of the flagellomere); Mt $n$, metasomal tergites $(n=$ position of the metasomal tergite); $\mathrm{OOL}=$ ocello-ocular distance; $\mathrm{POL}=$ postocellar distance.

\section{RESULTS AND DISCUSSION}

\section{Heimbra Cameron, 1909 \\ Heimbra opaca (Ashmead, 1894)}

The available records indicate the presence of $H$. opaca in a large number of localities from arid and semiarid regions of western USA and Mexico (Stage \& Snelling 1986). This is the first record from the Neotropical Region, in a Brazilian savannah (Cerrado) area of the Distrito Federal (Brasília).

Material examined. BRAZIL, Distrito Federal, Res.[erva] Ecol.[ógica do] IBGE, BR $251 \mathrm{~km}$ 0. 12-15.XII.[19]83. 36-33-1 J, 1 female (IBGE).

\section{Heimbra bicolor Subba Rao, 1978}

In Brazil, H. bicolor was cited for the State of Minas Gerais (Pedra Azul) (Stage \& Snelling 1986).

Herein we present a new record for a Brazilian savannah (Cerrado) area in the Distrito Federal (Brasília) and to a Brazilian dry forest (Caatinga) area, in the western region of Rio Grande do Norte State (Mossoró).

Material examined. IBGE: 1 female from BRAZIL, Distrito Federal, Res.[erva] Ecol.[ógica do] IBGE, BR $251 \mathrm{~km} \mathrm{0,} \mathrm{10-17.XII.[19]81,} \mathrm{cod.}$ 3A-84-9M. LRRP: 3 females from BRAZIL, R[io Grande do] N[orte], Mossoró, Fazenda Santa Júlia, 0501'10"S / 37²2'56"W, Malaise trap, Caatinga, 6.III.2007, D.R.R. Fernandes, col.[etor]; 2 females, same data except 14.IV.2007.

\section{Heimbra parallela Stage \& Snelling, 1986}

H. parallela was recorded from the Provinces of Salta (Salta), Entre Ríos (Pronunciamento) and Misiones (Santa Ana) in Argentina and from the States of São Paulo (São Paulo) and Paraná (Curitiba), in Brazil (Stage \& Snelling 1986). A new record for the State of São Paulo is added, from a specimen collected in a Brazilian savannah (Cerrado) area at the municipality of Luis Antonio.

Material examined. LRRP: 1 female from BRAZIL, S[ão] P[aulo], Luiz Antônio, Estação Ecológica de Jataí, 21³5’16"S / 4747’44"W, Malaise trap, cerrado, 9.XI.2006, N. W. Perioto et al.

\section{Symbra Stage \& Snelling, 1986}

\section{Symbra potiguara Perioto \& Fernandes sp. nov.}

$$
\text { (Figs. 1-4) }
$$

Female holotype: length $4.9 \mathrm{~mm}$. Primarily dark brown except scape, lateral panel of pronotum, tegula, latero-apical portion of scutellum, Mt 4-8, and legs dark reddish brown; body pilosity silvery white; anterior wing infuscated, submarginal vein light brown basally, apical portion of submarginal, marginal, stigmal and postmarginal veins brown; pilosity brown (Fig. 1).

Head (Fig. 2) 1.3x wider than high, with large, closely spaced, foveate sculpture with interstitial texture coriarious over entire surface except by a smooth, glabrous and shiny clypeus and scrobal depression with shiny and conspicuously strigate surface; foveate punctures, each bearing a large, silvery-white setae whose length is 1.1-1.4x the diameter of puncture; posterior ocelli closer to eye margin than to each other $(\mathrm{POL} / \mathrm{OOL}=2.7)$; interantennal area $0.5 \mathrm{x}$ higher than scrobal depression. Antenna (Fig. 2): scape long, extending to median ocellus, 5.8x basal (maximum) width; pedicel $0.7 x$ longer than wide; F1 (2.4x), F2 and F3 (2.1x), F4 and F5 (1.9x), F6 (1.7x), F7 (1.2x), and club (2.8x) longer than wide.

Mesosoma: dorsally (except tegulae) (Fig. 3) 1.8x longer than wide; sculpture and vestiture of thoracic dorsum similar to that of the head; the punctures are somewhat larger and possess slightly longer hairs on lateral panels of pronotum and postero-lateral portions of mesoscutum and scutellum; anterior pronotal carinae present only laterally; notaulus complete; scutellum $1.5 x$ longer than wide; dorsal prominence of scutellum conspicuous and acute in lateral view, located near the apical third portion; propodeum dorsally with large, strong square carinae diagonally on meson. Anterior wing with marginal vein almost twice the length of stigmal vein; postmarginal vein as long as marginal vein.

Metasoma: Mt 2+3 laterally and dorsally with sculpture and vestiture similar to that of head and dorsum of mesosoma (Fig. 4); the punctures have larger diameter dorsally, becoming smaller ventrally, with diameters ranging from half to one third of the dorsal punctures; Mt 6+7 with rounded apex 

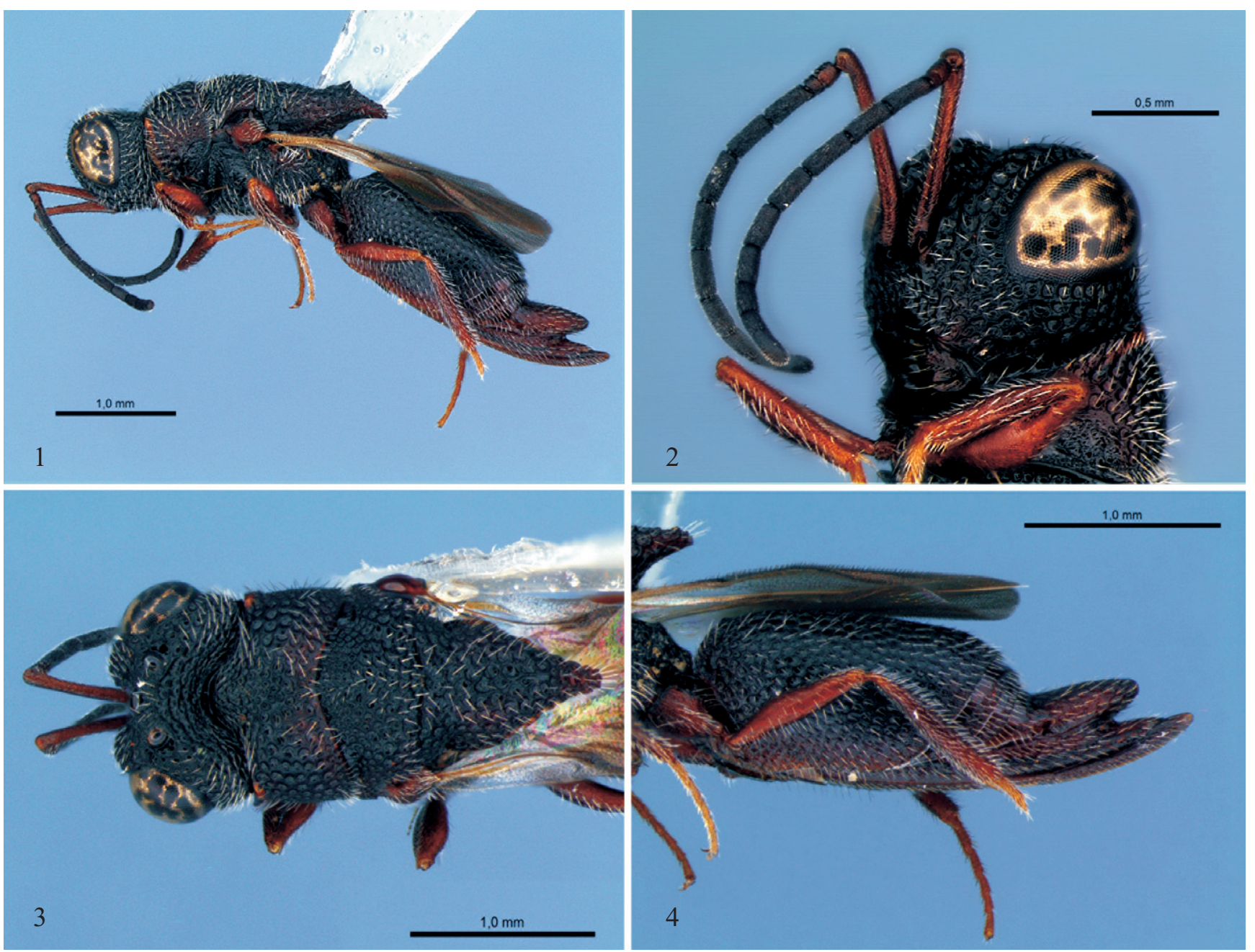

Figs. 1-4. Symbra potiguara Perioto \& Fernandes sp. nov. Female holotype. 1, habitus; 2, head; 3, mesosoma; 4, metasoma.

and without conspicuous mesal keel or conspicuous transverse groove; exposed portion of Mt 8 very long, more than twice the length of hind femur.

Male: unknown.

Distribution: Rio Grande do Norte, Brazil.

Comments: Symbra potiguara sp. nov. is similar to $S$. cordobensis and can be distinguished by presenting dark brown color; length of antennal scape nearly $6 \mathrm{x}$ maximum width near base; scutellum, dorsally, 1.5 times longer than wide, distance between the basal margin of scutellum and apex of scutellar prominence about $0.67 x$ length of scutellum and apex of Mt 6+7 rounded.

Material examined: female holotype: BRAZIL, R[io Grande do] N[orte], Mossoró, Fazenda Santa Júlia, 0501'10"S / 37²2' 56"W, Malaise trap, Caatinga, 6.III.2007, D.R.R. Fernandes, col.[etor]. Deposited in MZSP (Museu de Zoologia da Universidade de São Paulo, São Paulo, Brazil; C. R. F. Brandão, curator).

Etymology: the specific epithet, a noun in apposition, refers to a native tribe of the Tupi-Guarani linguistic family, the Potiguara that lives in the State of Rio Grande do Norte.

\section{Key to genera of Heimbrinae (adapted from Stage \&} Snelling, 1986), and species of Symbra

1. Antenna 13-segmented with 3-segmented club; flagellar segments broader than long; scutellum with lateral, subapical margins concave in dorsal view .... Heimbra Cameron.

1'. Antenna 11-segmented with undivided club; flagellar segments longer than broad; scutellum with lateral, subapical margins convex in dorsal view .. Symbra Stage \& Snelling ... 2

2. Predominantly black; length of antennal scape nearly $7 x$ maximum width near base; scutellum, dorsally, 1.1x longer than wide, distance between the basal margin of scutellum and apex of scutellar prominence about $0.75 x$ length of scutellum; apex of Mt 6+7 acuminate

S. cordobensis Stage \& Snelling

2 '. Predominantly dark brown; length of antennal scape nearly 6x maximum width near base; scutellum, dorsally, $1.5 x$ longer than wide, distance between the basal margin of scutellum and apex of scutellar prominence about $0.67 x$ length of scutellum; apex of Mt 6+7 rounded S. potiguara Perioto \& Fernandes sp. nov. 


\section{ACKNOWLEDGEMENTS}

We thank the Instituto Nacional de Ciência e Tecnologia dos Hymenoptera Parasitoides da Região Sudeste Brasileira (Hympar/Sudeste - CNPq/Fapesp/CAPES), for the financial support and to CAPES for the PhD scholarship granted to DRRF.

\section{REFERENCES}

Gates, M. G. \& P. E. Hanson. 2006. Family Eurytomidae, p. 380-387. In: Hanson, P. E. \& I. D. Gauld (eds.). Hymenoptera de la Región Neotro- pical. Issue 77 of Memoirs of the American Entomological Institute. Gainesville, The American Entomological Institute, 994 p.

Gibson, G. A. P. 1997. Morphology and terminology, p. 16-44. In: G. A. P. Gibson; J. T. Huber \& J. B. Wooley (eds.). Annotated keys to genera of Nearctic Chalcidoidea (Hymenoptera). Ottawa, NRC Research Press, 794 p.

Harris, R. A. 1979. A glossary of surface sculpturing. Occasional Papers in Entomology 28: 1-31.

Noyes, J. S. 2007. Universal Chalcidoidea Database. Available from: http:/ /www.nhm.ac.uk/chalcidoids (acessed 19 September 2007).

Stage, G. I. \& R. R. Snelling. 1986. The subfamilies of Eurytomidae and systematics of the subfamily Heimbrinae (Hymenoptera: Chalcidoidea). Contributions in Science 375: 1-17. 